\title{
The Ecological and Social Costs of Economic Development and Their Influence on Management in Europe
}

\author{
Robert Janik \\ Faculty of Management, Częstochowa University of Technology, Poland
}

Copyright (C) 2015 by authors, all rights reserved. Authors agree that this article remains permanently open access under the terms of the Creative Commons Attribution License 4.0 International License

\begin{abstract}
This article reviews the appearance of ecological and social costs of economic development within the globalization process for illustrating their influence on European management especially focusing on ecology. The article concludes that the process of European unification is successful in many areas but also faces a lot of problems and challenges. To the very important ones belong the social inequalities, unemployment and the destruction of nature. Thanks to the development of science and technology the creation of new economical activities in Europe is possible. They can help to create new possibilities for both, the solving of the ecological problems and to create jobs in many sectors of economy. The contemporary management should play a very important role in this process. Europe as one of the first continents which started the dynamic process of industrialization and destroying of nature can also be the first one to unite the contemporary economy with pro-economical activities. This would allow to connect the solving of social and ecological problems.
\end{abstract}

Keywords Globalization, Europe, Unemployment, Ecology, Management, Pollution, Environment

\section{Introduction}

The article starts with an introduction into the process of globalization and illustrates the challenges resulting from economical development. It continues with the formulation of problems: Do possibilities exist to reduce the ecological and social costs of economical development? If the answer is "yes" - in which way can this be achieved? Can environmental management create an alternative? Hence the hypothesis was formulated: It is possible to reduce the ecological and social costs of economic development by combining economic activities with pro-ecological ones within the environmental management. In the process of gathering dates the documentary research method was used. [1 pp. 173-451]

\section{The Globalization Process}

Since the end of the Second World War the globe seems to shrink rapidly, increasing the mutual relationships between its particular regions surprisingly quickly. As a result, over the past decades, the term "globalization" has emerged, becoming a synonym for progress and prosperity for its proponents, while for its opponents it became a slogan for a reactive system of capitalistic exploitation. Despite the continual controversy concerning the term's origin and conditions of emergence, its procedural character and global influence on economics, as well as on the exchange of goods and information, is undoubted. [2 p. 547]

The 21 st century appears to be a particular time in the history of mankind. The processes commenced in the previous centuries are leading to a transformation of lifestyle on an unprecedented scale. [3 pp. $104-108$ ] There are also positive achievements of civilization as evidenced by the elimination of certain illnesses, limitation of famine and the general if unbalanced technical development. [4 p. 2124]

\section{Negative Effects of Globalization}

However, there is also a multitude of negative effects of running such policies as exploiting the natural resources of the Earth in a manner that is not thought out but rather more like plundering. "Large areas of the Earth's surface, especially in arid and semi-arid regions, have been used for agricultural production for millennia, yielding crops for ever-increasing number of people. Concerns about the relationship between population growth and environmental degradation are frequently focused rather narrowly on aggregate population levels. Yet, the global impact of humans on the environment is as much a function of per capita consumption as it is of overall population size. For example, the Unites States comprises only 6 per cent of the world's population, but it consumes $30-40$ per cent of our planet's natural resources. Global overconsumption and uncontrolled population growth present a serious problem to the environment. Unless we are willing to change the 
underlying cultural and religious value structure that has combined with the social and economic dynamics of unrestrained capitalist accumulation, the health of Mother Earth is likely to deteriorate even further." [5 pp. $85-86]$

Modern times are also characterized by a large dissonance emerging between the commonly declared slogans such as "human dignity" and "human rights" while the practices in force in many parts of the world greatly differ from these declarations. [6 p.185] This refers to a large extent to the issue of military conflicts as well as social and ecological imbalance. [7 p.175]

\section{Political Integration in Europe}

Another symptom of the changes reflecting the spread of globalization is the occurrence of "political integration", whose symptomatic symbol could be termed as the process of unification in Europe. Likewise, in other parts of the world the processes of "integration" are emerging - as exemplified by the American continent. The emergence of large transnational structures in the shape of the European Union admittedly does not signify the immediate disappearance of nations, but does however constitute a major step in the direction of transferring elements of the previously held power from a national level to that of a supra-national level. This is accompanied by the awareness among citizens of belonging to a greater organizational structure that transgresses the previous national boundaries, as well as creating within a continent a European cultural community. It is necessary to mention the practical side of this phenomenon - migration flows, spreading of familiarity with foreign languages, mixed marriages, use of different systems of education, as well as the impact of mass cultures on the inhabitants of various countries. This leads to the erosion of the existing concepts of national states and the birth of new forms of ethnic and cultural identities.

In the logic of the integration processes, the shift of the burden from the centre to the lower organizational levels is a natural sequence of events. This particularly refers to those countries which consist of culturally "independent" provinces or possess significant ethnic minorities e.g. in the case of the EU there is a clear strife towards the passing on of some of the responsibility for decision-making and their realization in the case of the regions in question. This helps to release ethnic tension to a certain extent in the case of the occurrence of separatist trends in some countries.

\subsection{Problems and Challenges}

The process of European's unification is in many areas successful but also faces a lot of problems and challenges. To the very important ones belong the social inequalities, unemployment and the destruction of nature. "Transboundary pollution, global warming, climate change, and species extinction are challenges that cannot be contained within national or even regional borders. They do not have isolated causes and effects. They are global problems, caused by aggregate collective human actions, and thus require a coordinated global response. To be sure, ecological problems aggravate by globalization also have significant economic ramification. Although these effects will be more significant for less developed countries than for rich countries, they will nonetheless affect all people and all nations. [...] They are economic, political, cultural but above all ethical issues that have been expanded and intensified by globalization processes." [5 p.90]

In contemporary times, we are also faced with a rich variety of production techniques - many of which are deemed to be "damaging for the natural environment" are in fact even tolerated by the same politicians who refer to the need to protect the "natural resources" of our planet. Much points to the fact that in the period of the industrial revolution an unwritten rule was created with regard to the priority of economic interests over the protection of the natural environment, thus facilitating the realization of policies of economic growth while ignoring the impact this has on nature to a serious extent. However true to say that the dramatic effects of degradation of the Earth's resources finally forced the inclusion of ecological issues in the economic sphere, the practice of "choosing the lesser evil" is still very much in evidence today- the so-called situation of conflict between economic and ecological interests, at the expense of the latter ones. "What is currently at stake is the conservation of the Earth and the biosphere, the thin layer that is the scene of all of life. Desertification, deforestation, erosion, ozone depletion, acid and the greenhouse effect are just a few of the threats facing us. Another spectre is that of nuclear war, which would certainly be the end of everything. Human suffering and the destruction of Nature are everyday realities. At the same time, the call for action is becoming louder. Something must be done before Man effectively destroys the world; this awareness is gaining ground at all levels [...] The question is: how can we turn the tide, how can we create and preserve a future for coming generations, with adequate scope for nature and a healthy environment?" [8 p.9]

Significant changes have occurred over the last few years in the sphere of agriculture. The so-called "mad cow's disease" or foot and mouth disease showed the limits of industrial fattening of animals - the spongy degeneration of the brain is however only one of many possible dangers that are associated with the policy of maximizing profits in agriculture at all costs. Mass production of cheap food entails negative consequences for the health that are difficult to foresee - mainly due to the use of chemical substances in agriculture. The acceptance of genetically manipulated food on the market which has not been sufficiently tested in a process of long term tests would appear to be particularly controversial. It is also important not to forget about the ecological costs of mass fattening of animals. It is necessary to consider the sense of changing the form of production perhaps working out a pro-ecological form of agricultural production which would take the form of producing healthy 
food that does not destroy the natural environment and would provide increased possibilities of employment. We should move away from large breeding farms which produce unhealthy food in a manner that is harmful to the environment. "Another significant ecological problem associated with population increases and the globalization of environmental degradation is the worldwide reduction of biodiversity. Seven out of the biologists today believe that the world is now in the midst of the fastest mass extinction of living species in the 4.5-billion-year history of the planet. According to recent OECD reports, two-thirds of the world 's farmlands have been rated as "somewhat degraded". Half the world's wetlands have already been destroyed, and the biodiversity of freshwater ecosystems is under serious threat. Three-quarters of worldwide genetic diversity in agricultural crop and animal breeds has been lost since 1900. Some experts fear that up to 50 per cent of all plant and animal species - most of them in the global South - will disappear by the end of this century." [5 p.87]

Constructive steps on the road to improving the situation in agriculture are hindered by the "agrarlobby" which benefits from the current situation, which is witnessed not so much in terms of the numbers of citizens employed in agriculture as in terms of the economic and political potential at its disposal. [9]

\subsection{Pro - Ecological Economy}

Laws to prevent environmental destruction should be connected with pro-ecological economic activities. This is a very important source of the creation of new jobs. [10]. A particular area of activities in welfare states should be efforts aimed at preventing the negative effects of the process of globalization. [11 p. 513] Many proposals have been repeatedly offered by governments of particular countries aimed at the elimination of the possibilities of various abuse both on the part of particular producers and states themselves. [12 p. 97] The important macro-political moves by EU member countries which have an influence on the liquidation of unemployment and the development of the process of integration can be listed as follows:

- Continuation of unification of EU law;

- Expansion of the common trading policy;

- Intensification of efforts to create a common market by abolishing restrictions in the movement of goods, people, services and capital between EU member countries;

- Carrying out a common social policy in the EU;

- Supporting the construction and expansion of communication routes in Europe;

- cooperation in the area of agriculture and fishing;

- Working out a system that prevents counterfeiting by criminal gangs;

- Making contributions towards maintaining the high level of healthcare in the EU, strengthening industrial competitiveness in the EU - among other methods, by the implementation of new technologies;
- Subsidizing research and technological development;

- Unifying policies in the area of aid for developing countries; intensifying efforts for the improvement of consumer protection;

- Common activity in the sphere of energy, prevention of catastrophes and the expansion of communication routes.

Recently, there has also been an increase in the significance of eco-tourism, whose services are availed of by an increasing number of health conscious people. Unhealthy living conditions that exist in large city agglomerations encourage people to search for alternatives both in the form of "healthy" holidays or a few days of rest e.g. on Saturdays and Sundays, while also in the form of changing lifestyles and way of living - evidence of this is shown in the increase of "green belts" in city areas. The afore-mentioned changes create new jobs and lead to the formation of healthier habits that are safer for the natural environment. [13 p.165]

Maintenance of the established social standards as a result of international agreement forcing capitalists to take responsibility for the businesses run on the countries of their choice - mainly by adhering to legal and tax systems. Without questioning the sense of such a step it is important to note that in present times the failure to take any measures comes in conflict with western states which have possibilities at their disposal to force economic magnates to run a more pro-social form of economic activity. Companies which focused on profit apply the concept of "moving capital", which means moving the production to countries where they have access to a cheaper workforce and greater tax grace. More detailed analysis indicates that this is by no means the end of the moving capital - very frequently products made this way are returned to the company's mother country with the aim of selling the goods there as the place where the goods originated does not usually have appropriate dynamics of purchasing power - due to poverty of those societies. This is connected with the fact that western countries are still the most powerful market, which makes them attractive for various producers. If such a procedure was not possible the western countries instead of receiving such products with open arms would block their access to the market by indicating the dishonesty of such practices and firms with moving capital would in the fear of losing profits be definitely more careful about making decisions to move production facilities abroad.

Regardless of the use of these possibilities of action the developed countries should strive to reduce the costs of production, as these amounts are often associated with the need to finance various undertakings in the form of "additional costs" - e.g. social care. Aside from this, it is important to add that the amount of earnings of employees in western Europe is not very economically motivated relatively speaking - it is influenced by other factors- e.g. tariff conditions. [14 pp.109-123] 


\section{Conclusions}

In the course of the research the hypothesis "It is possible to reduce the ecological and social costs of economic development by combining economic activities with pro-ecological ones within the environmental management" was verified. Thanks to the development of science and technology the creation of new economical activities in Europe is possible. [15 pp.38 - 48] They can help to create new possibilities for both, the solving of the ecological problems and to create jobs in many sectors of economy. The contemporary management should play a very important role in this process. Europe as one of the first continents which started the dynamic process of industrialization and destroying of nature can also be the first one to unite the contemporary economy with pro-economical activities. This would allow to connect the solving of social and ecological problems.

\section{REFERENCES}

[1] Kiess HO. Statistical Concepts for the Behavioral Sciences. Boston, London, Sydney, Toronto: Allyn and Bacon; 1989.

[2] Giddens A. Sociology. 2nd ed. Oxford: Polity Press; 1993.

[3] Toffler A, Toffler H. Creating a New Civilization. Atlanta: Turner Publishing inc; 1995.

[4] Kromołowski H. Best Practices in Public Hospital Crisis Management. In: Bylok F, Ubreziova I, Cichobłaziński L, editors. Management and Managers Facing Challenges of the
21 st Century. Theoretical Background and Practical Applications. Hungary: Wyd. Godollo; 2014.

[5] Steger MB. Globalization. Oxford, New York: Oxford University Press; 2009.

[6] Fukuyama F. After the Neocons - America at the Crossroads. London: Profile Books; 2007.

[7] Akerlof GA, Shiller RJ. Animal Spirits, Princeton: Princeton University Press; 2009.

[8] Brundtland B. Green Development in the 1990s. New York: New Horizons Press; 1990.

[9] Röscheisen H. Die Umweltpolitik von 1982-1998 aus der Sicht der Umweltverbände. Historisch-Politische Mitteilungen. 2013 Jan; 13 (1): 205-210.

[10] Galbraith JK. The Affluent Society. Great Britain: Pelican Book; 1963.

[11] Harrod RF. John Maynerd Keynes, Middlesex: Pelican Books 1972.

[12] Drucker PF. Post - Capitalist Society. New York: Harper Business; 1993.

[13] Parsons T. The system of modern societies. London: PrenticeHall International INC; 1971.

[14] Janik R. Political and Economic Context of the Debate on „Human Capital” within the EU. In: Bylok F, Cichobłaziński L, editors. The Role of Human Capital in Knowledge Based Management. Częstochowa: Politechnika Częstochowska; 2011.

[15] Bylok F. Chosen Aspects of Managing Social Capital in Enterprises. In: Horska E, Ubreziova I, editors. Modern Management in the 21st Century. Theoretical and Practical Issues. Monograph. Nitria: GARMOND Nitra; 2013. 